\title{
Strategic Management of Organization Development and Civil Service Based Pumpinghr Model at Ibn Khaldun University Bogor
}

\author{
Amir Tengku Ramly and Dudung Abdul Syukur \\ Ibn Khaldun Bogor University \\ amir.tengkuramly@uika-bogor.ac.id
}

\begin{abstract}
Ibn Khaldun University which is the oldest Islamic campus in the city of Bogor founded by ulama leaders has a future interest to be a modern, leading-edge private campus with strong Islamic roots. This study aims to get UIKA's human resource management strategy that can become a strategic human resource for the achievement of UIKA's mission vision. This study is evaluativedescriptive, scientific literature search results with secondary data and modern theories of strategic management. UIKA's human resource development starts from creating strategic plan, UIKA's future organizational structure and determining three important competency standards, namely (1) core competency standard, and (2) managerial competency standard, and (3) Supporting Competency.
\end{abstract}

Keywords: Human Resources, Strategic Management, Competence

\section{Pendahuluan}

Manajemen strategis adalah seni dan ilmu dalam penyusunan, penerapan, dan pengevaluasian. Manajemen strategis merupakan aktivitas manajemen tertinggi yang biasanya disusun oleh dewan direksi dan dilaksanakan oleh CEO serta tim eksekutif organisasi tersebut. Manajemen strategis memberikan arahan menyeluruh untuk perusahaan dan terkait erat dengan bidang perilaku organisasi. Manajemen strategis berfokus pada proses penetapan tujuan organisasi, pengembangan kebijakan dan perencanaan untuk mencapai sasaran, serta mengalokasikan sumber daya untuk menerapkan kebijakan dan merencanakan pencapaian tujuan organisasi. Manajemen strategis mengkombinasikan aktivitas-aktivitas dari berbagai bagian fungsional suatu bisnis/aktifitas untuk mencapai tujuan organisasi. Ada tiga tahapan dalam manajemen strategis, yaitu perumusan strategi, pelaksanaan strategi, dan evaluasi strategi.

Manajemen strategis berbicara tentang gambaran besar. Inti dari manajemen strategis adalah mengidentifikasi tujuan organisasi, sumber dayanya, dan bagaimana sumber daya yang ada tersebut dapat digunakan secara paling efektif untuk memenuhi tujuan strategis. Manajemen strategis di saat ini harus memberikan fondasi dasar atau pedoman untuk pengambilan keputusan dalam organisasi. Ini adalah proses yang berkesinambungan dan terus-menerus. Rencana strategis organisasi merupakan dokumen hidup yang selalu dikunjungi dan kembali dikunjungi. Bahkan mungkin sampai perlu dianggap sebagaimana suatu cairan karena sifatnya yang terus harus dimodifikasi. Seiring dengan adanya informasi baru telah tersedia, dia harus digunakan untuk membuat penyesuaian dan revisi. 
Universitas Ibn Khaldun Bogor yang lahir tahun 1961 merupakan universitas tertua swasta di Bogor yang didirikan oleh para pejuang bangsa lintas ilmu dengan mengedepankan nilai-nilai syar'i dalam visi dan misi pengajarannya. Visi universitas ibn khaldun menjadi "Universitas Unggul Berbasis keislaman dan Teknologi Pada Tahun 2025". Adapun misi universitas Ibn Khaldun adalah: (1) menyelenggarakan program pendidikan tinggi yang unggul berbasis nilainilai keislaman dan penerapan teknologi, (2) mengembangkan ilmu pengetahuan, teknologi, dan seni untuk kesejahteraan masyarakat sebagai perwujudan keagungan ajaran Islam, dan (3) mengembangkan kerjasama dalam lingkungan nasional, regional, dan internasional dalam pelaksanaan program tridharma perguruan tinggi.

Tujuan universitas Ibn Khaldun adalah (1) menjadi Universitas Islam yang memiliki keunggulan dalam proses pembelajaran, penelitian dan pengabdian kepada masyarakat yang berbasis nilainilai keislaman dan penerapan teknologi, (2) menghasilkan insan akademik yang berakhlak mulia, kreatif, inovatif, dan relevan dengan dinamika kebutuhan masyarakat, (3) menghasilkan ilmu pengetahuan, teknologi, dan seni yang dapat meningkatkan kualitas kesejahteraan masyarakat sesuai dengan ajaran Islam, dan (4) terjalinnya kerjasama dalam lingkup nasional, regional, dan internasional dalam pelaksanaan program tridharma perguruan tinggi. Berdasarkan visi, misi dan tujuan tersebut maka UIKA dalam pengelolaannya membutuhkan SDM pegawai (tenaga kependidikan) dan dosen yang berkualitas yang memiliki peran strategis dalam pencapaian visi, misi dan tujuan Universitas Ibn Khaldun Bogor.

Penelitian ini bertujuan mendeskripsikan pentingnya UIKA dalam pengembangan organisasinya kedepan menggunakan strategic management dengan memperhatikan sejarah berdirinya UIKA, visi misi, dan tridharma perguruan tinggi. Penelitian ini akan menjawab 3 permasalahan dasar, yaitu (1) apakah yang menjadi focus pengembangan UIKA kedepan?, (2) apakah yang menjadi strategic plan UIKA dalam pengembangan organisasinya?, dan (3) bagaimana menerapkan prinsip pengembangan SDM PumpingHR Model dalam MSDM strategic UIKA?

\section{Kajian Pustaka}

\section{Manajemen Strategik}

Manajemen strategic menurut Harrison (2003) sangat erat hubungannnya dengan keunggulan kompetitif yang dalam prakteknya terdiri dari analisis, keputusan dan aksi dari organisasi. Menurut sampurno (2011) definisi tersebut mencakup dua elemen penting yang menjadi inti dari manajemen startegik, yaitu (1) tiga ongoing process (analisis, keputusan, aksi) dan (2) studi mengetahui mengapa organisasi dapat mempunyai kinerja yang lebih baik dibanding dengan yang lain. Manajemen strategic focus pada pertanyaan fundamental: "bagaimana organisasi dapat bersaing dengan menciptakan keunggulan bersaing di pasar, tidak hanya sekedar karena unik dan bernilai tetapi juga sulit bagi pesaing untuk menirunya?" (Sampurno, 2011).

Menurut Michael Porter dalam Sampurno (2011) keunggulan bersaing yang berkelanjutan, yang tidak bisa di tiru tidak dapat diperoleh hanya melalui efektifitas operasional. Keunggulan daya saing yang berkelanjutan (sustainable) hanya dapat dicapai melalui aktifitas dengan strategi yang baik. Menurut Barney (1991) keunggulan daya saing yang berkelanjutan dapat dicapai apabila organisasi melaksanakan value creating strategy. Barney menekankan keunggulan bersaing berkelanjutan sangat ditentukan oleh sumberdaya strategis (strategic asset) dengan ciri-ciri: 
bernilai (valuable), langka (rare), tidak dapat ditiru (imperfectly imitable) dan tidak tergantikan (non Subtitutiable).

Ada empat atribut penting manajemen strategic, yaitu (1) terarah langsung pada tujuan organisasi, (2) melibatkan berbagai stakeholder dalam pengambilan keputusan, (3) diinkoporasikan pada perspektif jangka pendek maupun jangka panjang, dan (4) menengarai trade off antara efisiensi dan efektifitas (Des, Lumpkin \& Eishner dalam Sampurno, 2011). Dalam mempraktekkan manajemen strategic terdapat 5 tugas manajerial yang harus dilaksanakan, yaitu (1) mengartikulasikan visi strategic dan misi organisasi, (2) merumuskan tujuan yang merupakan konversi visi strategic menjadi kinerja spesifik yang harus dicapai oleh organisasi, (3) menyusun strategi untuk mencapai outcome yang dikehendaki, (4) implementasi dan eksekusi strategi, dan (5) evaluasi dan monitoring kinerja dan inisiasi corrective adjustment terhadap arah lembaga jangka panjang, tujuan, strategi atau eksekusi dan implementasi strategi (Thomson \& Strickland, 2003).

\section{MSDM Strategik}

Manajemen Sumberdaya Manusia (MSDM) strategic menurut Mangkuprawira (2004) mengacu pada bagaimana organisasi menggunakan karyawan dalam rangka memenangkan atau mempertahankan keunggulan bersaing terhadap pesaing. MSDM Strategik merupakan suatu system dimana terjadi keterkaitan antara MSDM dengan sasaran dan tujuan strategic organisasi dalam rangka meningkatkan kinerja perusahaan serta mengembangkan budaya organisasi yang mengadopsi inovasi dan fleksibilitas (Mathis \& Jackson, 2003). MSDM strategic berbicara mengenai integrase dan adaptasi yang konsentrasinya untuk memastikan bahwa (1) SDM sepenuhnya terintegrasi dengan strategi dan kebutuhan strategic organisasi, (2) Kebijakan SDM melekat baik melampaui area kebijakan maupun hierarki, (3) praktik SDM telah disesuaikan, diterima, dan digunakan oleh manajer lini dan karyawan sebagai bagian dari pekerjaan seharihari (Mangkuprawira, 2011).

Menurut Mello (2002) MSDM strategic meliputi 5-P, yaitu philosophy, policy, program, practice, dan process. Secara rinci kegiatan $5 \mathrm{P}$ itu adalah seperti pada Gambar 1 berikut ini (Mangkuprawira, 2011).

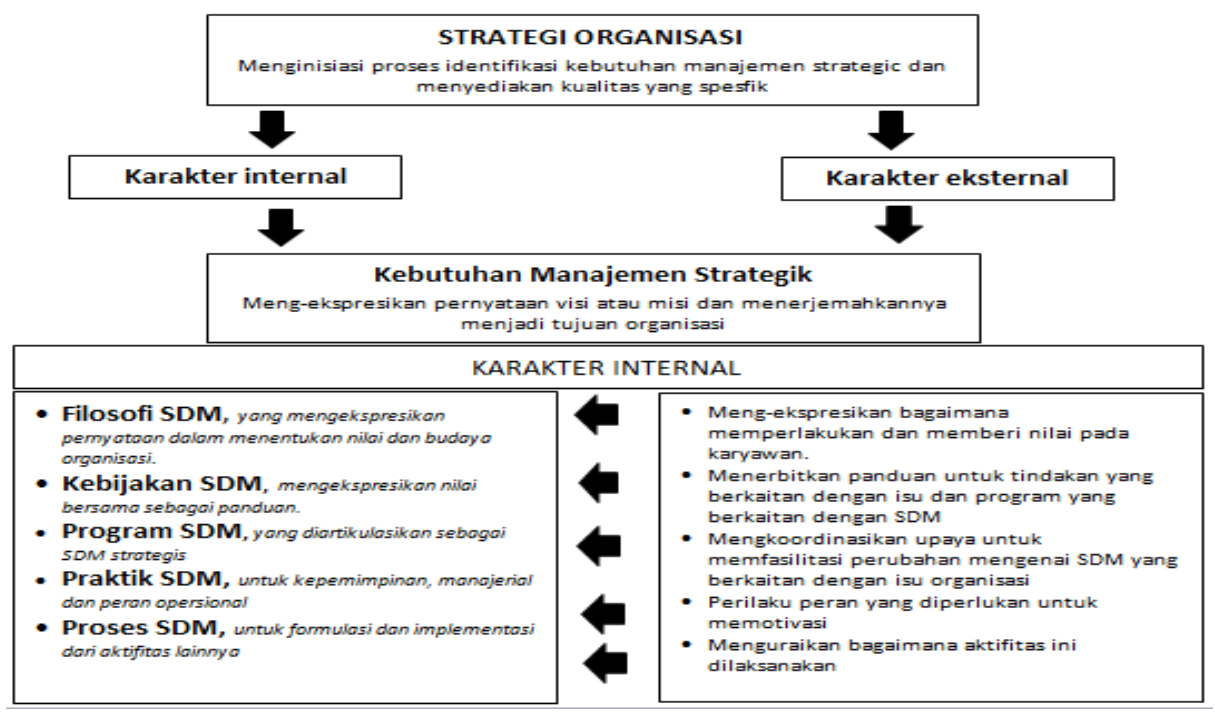




\section{Gambar 1. Kegiatan 5-P dalam Kebutuhan Manajemen dan MSDM Strategik}

Manajemen sumberdaya manusia (MSDM) merupakan bagian dari manajemen keorganisasian yang memfokuskan diri pada unsur sumberdaya manusia (Umar, 2005). Tugas MSDM adalah mengelola unsur manusia secara baik agar diperoleh tenaga kerja yang puas akan pekerjaannya.

\section{PumpingHR Model}

Pumping model merupakan karya intelektual peneliti yang telah diuji cobakan pada programprogram training selama 10 tahun sejak tahun 2004. Pumping model telah mendapat hak kekayaan intelektual (HAKI) dari kemenkumham dengan No Haki: IDM000427876, tanggal 15 Agustus 2011. Kerangka Pumping Model terbentuk dalam 3 fondasi utama yaitu pumping principle, pumping competence dan pumping action yang bersumber dari pendekatanpendekatan teori yang telah ada dan teruji secara ilmiah, yaitu:

- Menggunakan perumpamaan pohon yang baik yang terdiri dari akar, batang dan buah/daun (QS 14: 24)

- Bersandar pada prinsip-prinsip model milky way (tata surya) yang terdiri dari pusat orbit, titik orbit dan garis orbit.

- Bersandar pada teori Iceberg yang memperlihatkan 3 alam manusia, yaitu bawah sadar (unconsious), prasadar (pra-consious) dan alam sadar (consious).

- Bersandar pada teori-teori modern tentang anugerah manusiawi, yaitu pancaindera, otak, dan hati.

Tabel 1. Komponen PumpingHR model dalam berbagai Analogi

\begin{tabular}{|l|l|l|l|l|l|}
\hline \multirow{2}{*}{$\begin{array}{c}\text { Struktur/Komponen } \\
\text { Pumping HR model }\end{array}$} & \multicolumn{5}{|c|}{ Analogi } \\
\cline { 2 - 7 } & Pohon & Tata Surya & Manusia & & \\
\hline Pumping Principle & Akar & Pusat Orbit & Hati & Ikhsan & Iman \\
\hline Pumping Competency & Batang & Titik Orbit & Otak & Iman & Ilmu \\
\hline Pumping Action & Buah/daun & Garis Orbit & Pancaindera & Islam & Amal \\
\hline
\end{tabular}

Secara konsep Pumping model mengacu pada Al Qur'an dan teori-teori talent management serta competency management para pakar seperti David McClelland, Michael Armstrong, Gary S Becker, Angela Barron, Dave Ulrich, R Palan, Lance A Berger, Dorothy R Berger, Michael Zwell, dan lain-lain. Pumping model menggunakan konsep modal manusia, dimana didalamnya memadukan potensi bakat, perilaku, personal ability, professional ability, kompetensi intangible dan kecerdasan spiritual (SQ), kecerdasan emosional (EQ), serta kecerdasan adversity (AQ). Pumping model sebagai konsep human capital menekankan pentingnya pengembangan unsur manusia melalui penguatan nilai-nilai (value) menjadi kekuatan keyakinan (belief system), proses kesadaran diri (self awareness processs) dan mengeksplor (memompa) potensi-potensi terbaiknya sebagai perilaku dan karakter menuju pada kesuksesan diri. 


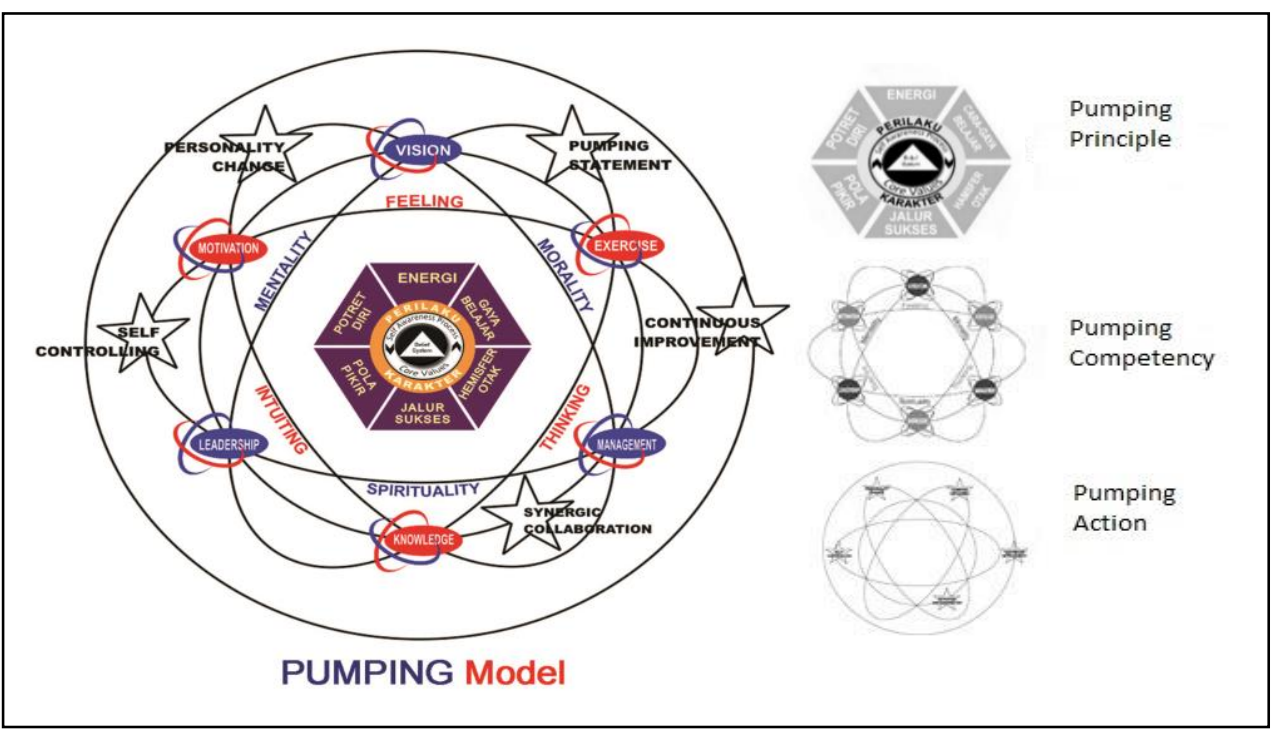

\section{Gambar 2. Konsep Pengembangan SDM based Pumping HR Model (Ramly, 2016)}

PumpingHR model mengandung aset-aset penting yang tidak tampak (intangible) yang sangat dibutuhkan individu dan organisasi, yaitu 4 prinsip sukses, 12 kompetensi dan 5 langkah tindakan (aksi) untuk sukses. Unsur-unsur nilai, kompetensi dan tindakan yang ada pada struktur pumping model yang dimaksu adalah seperti terlihat pada Tabel 2 berikut ini:

Tabel 2. Intangible asset dari Pumping HR Model

\begin{tabular}{|c|c|c|c|}
\hline \multirow[b]{2}{*}{ Prinsip Sukses } & \multicolumn{2}{|c|}{ Kompetensi Sukses } & \multirow[b]{2}{*}{ Tindakan Sukses } \\
\hline & K- Utama & K-pendukung & \\
\hline \multirow{6}{*}{$\begin{array}{l}\text { 1. Belief System } \\
\text { 2. Core Values } \\
\text { 3. Self Awareness } \\
\text { Process } \\
\text { 4. Personality } \\
\text { (Perilaku dan } \\
\text { Karakter Sukses) }\end{array}$} & 1. Visi & 7. Mentality & \multirow{6}{*}{$\begin{array}{ll}\text { 1. } & \text { Statement } \\
\text { 2. } & \text { Personality } \\
\text { Change } \\
\text { 3. Self Controling } \\
\text { 4. Network- } \\
\text { Collaboration } \\
\text { 5. Continuous } \\
\text { Improvement }\end{array}$} \\
\hline & 2. Leaderhip & 8. Morality & \\
\hline & 3. Manajemen & 9. Spirituality & \\
\hline & 4. Knowledge & 10. Intuiting & \\
\hline & 5. Motivasi & 11.thingking & \\
\hline & 6. Exercise & 12. Feeling & \\
\hline
\end{tabular}

Pumping HR model merupakan model pengembangan SDM dengan menggunakan prinsipprinsip Human Capital. Baron \& Armstrong (2007) mengatakan "Human capital is an important element of the intangible assets of an organization". Human capital tidak dimiliki oleh organisasi tetapi didapatkan melalui hubungan kerja dengan karyawan. Manusia mempunyai kemampuan bawaan, perilaku dan energy pribadi. Unsur-unsur ini membentuk human capital yang mereka bawa kedalam pekerjaannya (Davenport dalam Baron \& Armstrong, 2007). Hasil penelitian yang dilakukan Ramly (2016) menunjukkan bahwa pengembangan SDM dalam organisasi harus memperhatikan 3 hal penting, yaitu (1) karakter SDM, (2) kompetensi SDM, dan (3) perilaku SDM. Tiga komponen penting dalam Pumping HR Model tersebut mempengaruhi terhadap kesuksesan, motivasi dan produktifitas kerja karyawan. Sange (1996) mengajukan lima komponen penting dalam pengembangan diri dan organisasi pembelajar, yaitu 
(1) membangun visi bersama, (2) kompetensi (keahlian) pribadi, (3) berpikir system, (4) model mental, dan (5) pembelajaran tim.

\section{Metode Penelitian}

Penelitian ini dilakukan dua tahap, tahap pertama bersifat kualitatif-deskriptif melalui penelusuran literatur terkait hasil penelitian, sejarah, pedoman organisasi, kebijakan dan pendapat para pakar manajemen organisasi. Tahap kedua bersifat evaluative dengan survey dan wawancara. Menurut Sugiono (2005) penelitian kualitatif merupakan sebuah metode penelitian yang digunakan untuk mengungkapkan permasalahan dalam kehidupan kerja organisasi sehingga dapat dijadikan suatu kebijakan untuk dilaksankan demi kesejahteraan bersama. Masalah dalam penelitian kualitatif bersifat sementara, tentative dan akan berkembang atau berganti setelah peneliti berada di lapangan.

\section{Sumber Data Penelitian}

Dalam metodologi penelitian kualitatif, ada berbagai metode pengumpulan data/sumber yang biasa digunakan. Menurut Millan dan Schumacer (2001) paling sedikit ada empat strategi pengumpulan data dalam penelitian kualitatif, yaitu (1) observasi partisipatif, (2) wawancara mendalam, (3) studi literatur dan artefak, serta (4) teknik pelengkap. Menurut Bugin (2008) metode literatur adalah salah satu metode pengumpulan data yang digunakan dalam metodologi penelitian sosial untuk menelusuri data histories. Literatur merupakan catatan peristiwa yang sudah berlalu yang berbentuk tulisan, gambar, atau karya-karya monumental dari seseorang (Sugiono, 2005).

Metode atau studi literatur, meski pada mulanya jarang diperhatikan dalam metodologi penelitian kualitatif, pada masa kini menjadi salah satu bagian yang penting dan tak terpisahkan dalam metodologi penelitian kualitatif. Hal ini disebabkan oleh adanya kesadaran dan pemahaman baru yang berkembang di para peneliti, bahwa banyak sekali data-data yang tersimpan dalam bentuk literatur dan artefak. Sehingga penggalian sumber data lewat studi literatur menjadi pelengkap bagi proses penelitian kualitatif (Dapur Ilmiah, 2014). Bahkan Guba dalam Bugin (2008) menyatakan bahwa tingkat kredibilitas suatu hasil penelitian kualitatif sedikit banyaknya ditentukan pula oleh penggunaan dan pemanfaatan literatur yang ada.

\section{Metode Studi Literatur}

Metode studi literatur adalah serangkaian kegiatan yang berkenaan dengan metode pengumpulan data pustaka, membaca dan mencatat, serta mengolah bahan penelitian (Zed, 2008). Studi kepustakaan merupakan kegiatan yang diwajibkan dalam penelitian, khususnya penelitian akademik yang tujuan utamanya adalah mengembangkan aspek teoritis maupun aspek manfaat praktis. Studi kepustakaan dilakukan oleh setiap peneliti dengan tujuan utama yaitu mencari dasar pijakan / fondasi utnuk memperoleh dan membangun landasan teori, kerangka berpikir, dan menentukan dugaan sementara atau disebut juga dengan hipotesis penelitian. Dengan demikian para peneliti dapat menggelompokkan, mengalokasikan mengorganisasikan, dan menggunakan variasi pustaka dalam bidangnya.

Dengan melakukan studi kepustakaan, para peneliti mempunyai pendalaman yang lebih luas dan mendalam terhadap masalah yang hendak diteliti. Melakukan studi literatur ini dilakukan oleh 
peneliti antara setelah mereka menentukan topik penelitian dan ditetapkannya rumusan permasalahan, sebelum mereka terjun ke lapangan untuk mengumpulkan data yang diperlukan (Darmadi, 2011).

\section{Analisis}

Dari literatur yang didapatkan, peneliti membandingkan dengan hasil penelitian, pendapat para pakar dan visi-misi UIKA yang ada. Peneliti juga menggunakan prinsip-prinsip pengembangan institusi yang dalam sejarah UIKA sangat erat kaitannya satu sama lain, yaitu manajemen organisasi IPB. IPB banyak menghasilkan tokoh yang kemudian mengabdikan dirinya di UIKA sebagai bukti komitmen ke Islaman dan rasa tanggungjawab terhadap amanah para tokoh dan ulama pendiri UIKA. Dengan visi-misi yang ada, sejarah tokoh Ibn Khaldun dan motivasi para pendiri UIKA serta system manajemen organisasi UIKA saat ini yang ada, peneliti memetakan dalam teori-teori manajemen strategic dan hasil penelitian Pengembangan SDM berbasis Pumping HR model serta pendapat para pakar manajemen organisasi dan manajemen SDM strategic.

\section{Pembahasan Hasil}

Berdasarkan literatur sejarah pendirian, UIKA merupakan organisasi (universitas) tertua di Bogor yang membawa visi keislaman dalam pendidikan tinggi. Dilihat dari tokoh-tokoh yang menjadi pendiri UIKA merupakan orang-orang besar yang memiliki latarbelakang yang beragam, namun memiliki visi dan misi yang sama. Para pendiri UIKA dimaksud adalah (1) dr. Marzuki Mahdi, yang berlatarbelakang sebagai seorang dokter, yang namanya diabadikan sebagai RS Marzuki Mahdi di kota Bogor, (2) KH. Sholeh Iskandar, berlatarbelakang ulama dan pejuang yang namanya juga diabadikan sebagai nama jalan di kota bogor, (3) RSA Karta Djumena, (4) Ir. Prijono Hardjosentono, (5) Djunus Dali, (6) Ir. Imam Rahardjo, (7) RSA Suwigyo, dan (8) H.M Djunaedi.

Berdasarkan literatur nama Ibn Khaldun Bogor diambil dari nama seorang ilmuwan muslim bernama Ibn Khaldun yang hidup pada abad ke 14 Masehi, tepatnya beliau dilahirkan di Tunis 1 Ramadhan 732 Hijriyah (27 Mei 1332 Masehi) dan wafat di Kairo pada tanggal tanggal 25 Ramadhan 808 Hijriyah (19 Maret 1406 Masehi). Ibn Khaldun mempunyai nama lengkap Abu Zaid Abdurrahman Ibn Khaldun. Ibn Khaldun juga seorang Sosiolog dan Sejarawan terkenal dengan bukunya Mukaddimah. Beliau merupakan perintis filsafat sejarah dan sosiologi yang tidak ada tandingan pada zamannya. Mengingat beliau seorang ilmuwan besar muslim dan juga karena kebesaran jiwanya, maka para pendiri Yayasan Ibn Chaldun (Ibn Chaldun Foundation) mengabadikan namanya sebagai nama Yayasan maupun nama Universitas. Ibn Khaldun yang lahir di Tunisia dan besar di Mesir ini merupakan tokoh yang menguasai ilmu pengetahuan multidisipliner. Salah satu bukunya "The Muqadimah" yang disebutkan diatas, menjadi bacaan penting abad 21, bahkan CEO Facebook, Mark Zuckerberg, memasukan buku tersebut dalam 11 buku bacaan wajibnya.

Berdasarkan literatur visi misi lembaganya, UIKA memiliki visi misi "Menjadi Universitas Unggul Berbasis Keislaman dan Teknologi Pada Tahun 2025”.

Sedikitnya ada 3 hal besar dalam visi misi UIKA, yaitu: 
(1) universitas unggul, yakni berdaya saing kompetitif,

(2) nilai-nilai Islam, dan

(3) penguasaan teknologi modern.

Selain visi misi tersebut, hasil literatur UIKA juga memiliki konsep program Islamisasi sains dan kampus. Selain itu juga ada motto 'Toward leading Isamic University dan juga ada motto "iman, ilmu dan amal”. Berdasarakan literatur yang ada UIKA memiliki struktur organisasi seperti Gambar 3 berikut ini.

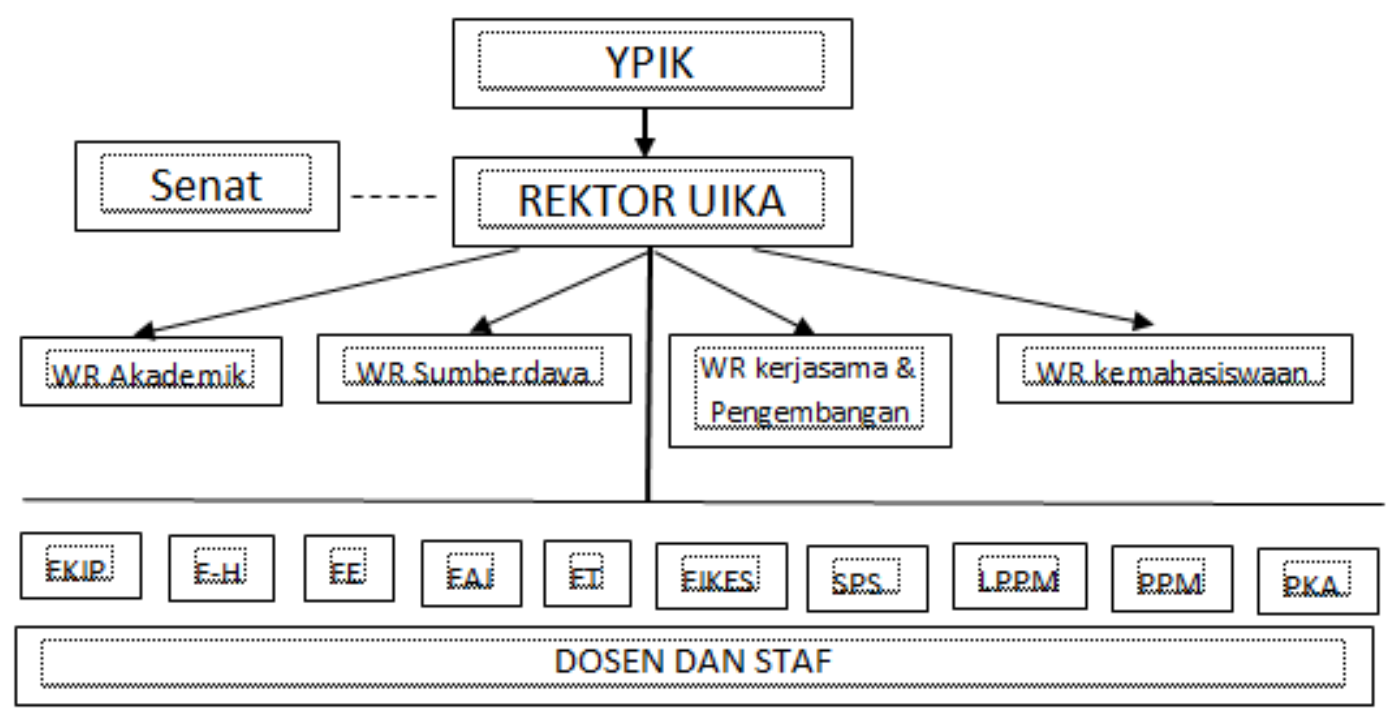

Gambar 3. Struktur Organisasi UIKA

Sumber: Buku Pedoman Akademik UIKA (telah diolah)

Berdasarkan literatur, UIKA memiliki norma-norma kehidupan (perilaku/artefak) yaitu: (1) mengembangkan sikap $3 \mathrm{~S}$ (Senyum-Salam-Sapa) saat bertemu; (2) berpenampilan rapih dan berpakaian Islami; (3) saling menghormati dan bertutur kata sopan santun sesuai Kaidah "Akhlak al-karimah"; (4) menghentikan semua kegiatan apabila terdengar kumandang "Adzan" dan bergegas untuk menunaikan sholat berjama'ah di masjid; (5) menjaga dan melestarikan lingkungan kampus; (6) menyelesaikan studi tepat waktu; (7) cinta dan haus ilmu pengetahuan serta berfikir kritis sesuai kaidah ilmiah; (8) senang dan aktif berorganisasi dalam kebaikan; (9) menjaga nama baik dan integritas almamater; (10) tidak berkhalwat di dalam lingkungan kampus. (11) tidak merokok di area kampus.

Para pendiri UIKA yang merupakan perpaduan tokoh dari berbagai profesi menunjukkan bahwa UIKA lahir atas keberagaman dan latarbelakang pendirinya yang mempersatukan mereka karena visi dan aqidah yang sama. Sebagai penghormatan pada para pendiri, maka fakultas-fakultas yang ada bisa mencerminkan keprofesian para pendirinya. Misalnya KH Sholeh Iskandar maka dicerminkan dengan ada nya fakultas agama Islam. Yang roh pendidikan harus diisi dengan semangat dan daya juang beliau sebagai pendakwah dan pejuang nasional. Fakultas yang sangat penting untuk menjaga semangat pendirian UIKA adalah fakultas kedokteran. Dengan adanya FK akan menjadi kekuatan bagi UIKA untuk terus maju dengan melahirkan dokter-dokter yang tidak hanya menguasai teknologi tetapi juga nilai-nilai Islam dalam praktek para dokter. 
Dari nama Ibn Khaldun yang digunakan pendiri menunjukkan kesungguhan para pendiri untuk melahirkan ilmuwan-ilmuwan Islam yang akan menjadi penerus ibn khaldun dalam perjuangan dan keilmuwannya. UIKA melahirkan sosok-sosok manusia pembelajar dengan berbagai penguasaan disiplin ilmu. Oleh karenanya sosok dan figure Ibn Khaldun harus menjadi motivasi awal mahasiswa UIKA. UIKA membutuhkan perubahan organisasi dan manajemen sesuai dengan kemajuan zaman dan tuntutan perubahan itu sendiri.

Untuk mewujudkan visi-misinya, UIKA perlu merancang strategic plan pengembangan UIKA dalam jangka panjang 25 sd 50 tahun kedepan. Sehingga setiap pergantian rektor akan menjadi pelanjut pencapaian visi-misi tersebut, dalam bentuk focus kebijakan tahunan dan 5 tahunan. UIKA tidak boleh mapan secara penataan lembaga dan pengembangan SDM nya, karena organisasi yang tidak siap berubah, maka akan mati. UIKA perlu mempraktekkan disiplin kelima sebagai organisasi pembelajar (Senge, 1995).

Organisasi yang dikembangkan dapat disesuaikan dengan pendekatan badan hukum milik negara (BHMN) atau untuk UIKA dapat disebut Badan Hukum Milik Yayasan (BHMY). Mengacu pada organisasi BHMN (IPB, 2013) setidaknya UIKA memiliki 5 organ utama, yaitu: (1) MajelisUIKA dan Senat Akademik, (2) Pengelola yaitu Rektor dan wakil rektor, (3) Pelaksana Akademik, terdiri dari Fakultas, lembaga Penjamin Mutu, LPPM, departemen, dan pusat studi, (4) Pelaksana Administrasi, yaitu direktorat dan kantor, dan (5) Penunjang Akademik yang meliputi perpustakaan, lab/bagian, bengkel, rumah sakit, satuan usaha, satuan keamananketertiban, dan bentuk lainnya.

Pimpinan UIKA perlu membangun visi bersama civitas akademika melalui kepemimpinan kampus yang inspiratif, intelektual dan transformative. Membangun visi bersama dapat dimulai dari pengembangan dosen dalam manajemen system dan strategic. Menurut Arwildayanto (2013) pengembangan SDM dosen sudah menjadi kebutuhan nyata bagi usaha perbaikan mutu perguruan tinggi melalui proses yang sistematis, runtut, terukur dan terorganisir dibawah kepemimpinan kampus yang baik.

Untuk norma-norma dan perilaku akademisi kampus (mahasiswa, karyawan dan dosen) perlu dilakukan penguatan 3 hal utama, yaitu (1) pemahaman secara prinsip (core values) UIKA sebagai Islamic University Culture, (2) perilaku dan tindakan-tindakan para akademisi sebagai individu dan tim UIKA, (3) kompetensi unggul sebagai ciri intelektual dan pekerja keras, cerdas dan ikhlas. UIKA harus merumuskan 3 standar kompetensi dasar bagi para civitas akademika UIKA, yaitu (1) core competency UIKA, (2) managerial competency UIKA, dan (3) supporting Competency UIKA.

Dalam penguatan kompetensi UIKA perlu mengembangkan manajemen kinerja dan indicator kinerja kunci dalam berbagai perspektif, seperti perspektif stakeholder, academic dan research, perspektif Quality Control Internal Process, dan perspektif ketokohan dan tim yang kuat. Seperti contohnya IPB dalam menyusun manajemen kinerja selalu dimulai dengan pertanyaan, bagaimana IPB dipandang oleh pemangku kepentingan, bagaimana cara menerjemahkan visi dan misi IPB melalui kegiatan yang menghasilkan keunggulan riset dan akademik (IPB, 2012). Sebagai gambaran standar penjaminan mutu secara komprehensif yang dimulai dari visi, akademik, non akademik sampai ke indicator kerja adalah seperti Gambar 4 berikut. 


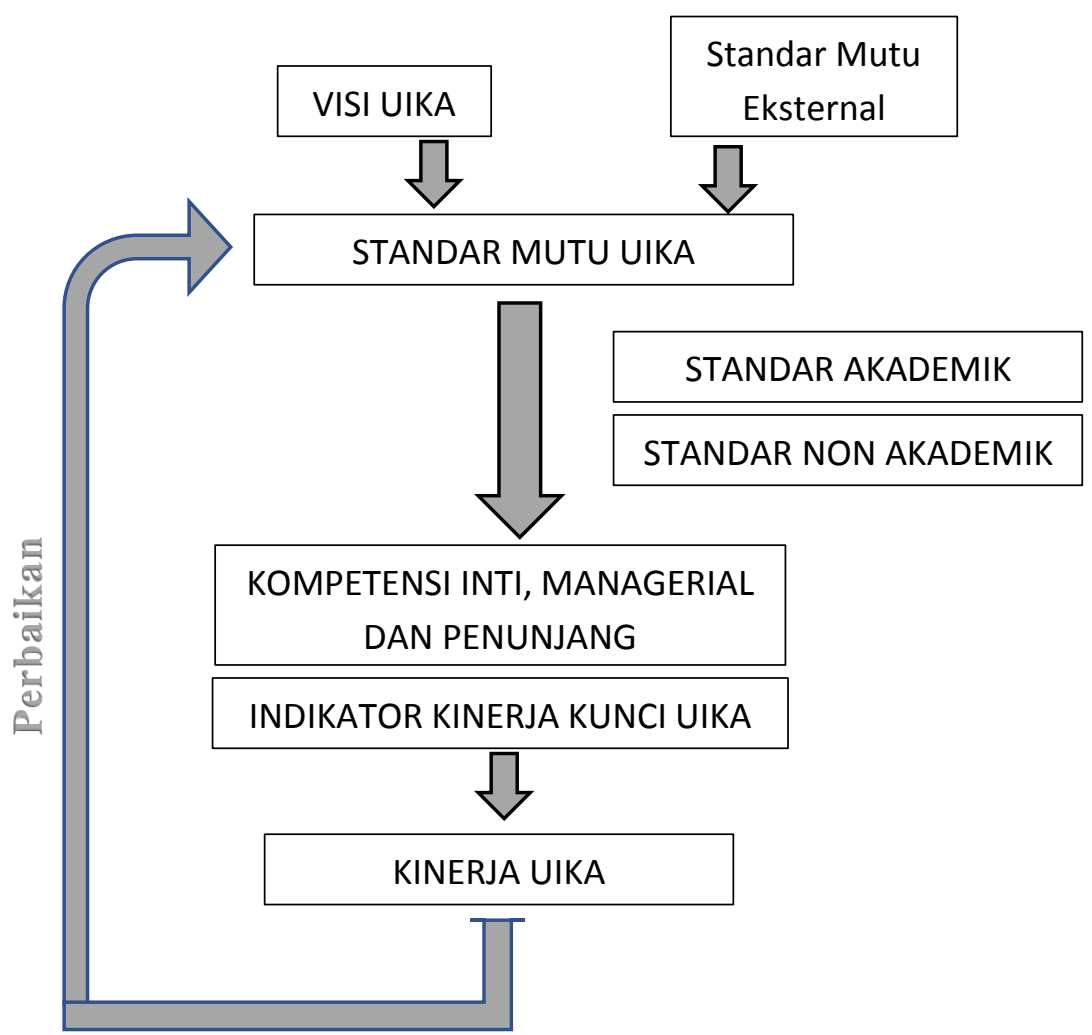

Gambar 4. Penentuan Kinerja UIKA secara menyeluruh

Sumber: IPB (2012) telah diolah.

\section{Kesimpulan dan Rekomendasi}

\section{Kesimpulan}

1. UIKA organisasi yang focus sebagai universitas dengan menghasilkan sarjana-sarjana yang menguasai ilmu multidispliner dengan basis nilai-nilai Islam yang kuat.

2. UIKA dalam mewujudkan visi misi nya membuat strategic plan terkait manajemen dan pengembangan organisasi kampus menuju Modern Islamic University sinergis dengan gagasan pemikiran Ibn Khaldun.

3. UIKA menerapkan pengembangan SDM strategic berbasis PumpingHR Model dengan 3 competency utama, yaitu (1) membangun core competency dengan nilai-nilai luhur pendiri dan muqadimahnya Ibn Khaldun, (2) mengembangkan managerial competency bagi dosen dan karyawan serta lulusan UIKA yang sinergis dengan Standar Kerja Kompetensi Nasional Indonesia (SKKNI), dan (3) menggunakan supporting competency individu dan tim civitas akademika dalam menghadapi dan menyelesaikan berbagai masalah.

\section{Rekomendasi}

- Perlu dilakukan penelitian lanjutan untuk memahami efektifitas SDM dan penataan organisasi UIKA saat ini dan disain organisasi serta MSDM strategic untuk mewujudkan visi misi dan tujuan pendirian UIKA. 
IJBE: Integrated Journal of Business and Economics e-ISSN: 2549-3280

- Penataan organisasi UIKA dapat mencontoh system penataan perguruan tinggi BHMN yang ada di Indonesia.

- Perlu revitalisasi nilai-nilai keIslaman dan university culture yang bersumber dari nilainilai dan gagasan ilmuwan Ibn Chaldun

- Nilai-nilai "Muqadimah" dapat dijadikan materi wajib dalam masa perkenalan kampus UIKA bagi mahasiswa baru, baik dalam bentuk ceramah, video, drama dan tau rekam jejak perjuangan ilmuwan Ibn Khaldun

- UIKA perlu membangun taman rektorat dengan artifak Ibn Khaldun sebagai semangat dalam menuntut dan mengembangkan ilmu pengetahuan dan keahlian para civitas akademika dan alumni UIKA Bogor

\section{Referensi}

Alquranulkarim. (2016). Alquran dan Terjemahan nya Edisi tahun 2002 oleh Kementrian Agama RI. Jakarta: CV Darus Sunnah.

Arwildayanto. (2013). Manajemen Sumberdaya Manusia Perguruan Tinggi, Pendekatan Budaya Kerja Dosen Profesional. Bandung: Alfabeta.

Baron, A. \& Armstrong, M. (2007). Human capital Management, Achieving Added Value Through People. London \& Philadelphia: Kogan Page.

Barney, J. (1991). Firm resources and sustained competitive advantage. Jurnal: Management Science, 17, 99-120.

Bugin, B. (2008). Penelitian Kualitatif; Komunikasi, Ekonomi, Kebijakan Publik dan Ilmu Sosial Lainnya. Jakarta: Kencana.

Darmadi, H. (2011). Metode Penelitian Pendidikan. Bandung: Alfabeta.

Dapur Ilmiah. (2014). Penelitian Literatur. Online:http://dapurilmiah.blogspot.co.id/ 2014/06/penelitianliteratur.html. Diunggah tanggal 9 November 2017.

Harrison, J. S. (2003). Strategic Management of Resources and Relationship. New York: John Wiley \& Sons, Inc.

IPB. (2008). Strategic Plan Bogor Agricultural University 2008-2013. Bogor: IPB

IPB. (2012). Indikator Kinerja Kunci Menuju IPB sebagai Learning Organization Unggul. Bogor: Simaker IPB

Jauhari, Heri. 2009. Pedoman Penulisan Karya Ilmiah. Bandung: CV. Pustakasetia.

Khaldun, I. (2015). Mukaddimah. Terjemahan. Jakarta: Alkautsar.

Mangkuprawira, S. (2011). Manajemen Sumberdaya Manusia Strategik. Bogor: Ghalia Indonesia.

Mathis, R. L. \& Jackson, J. H. (2003). Human Resource Management. 10 ${ }^{\text {th }}$ Edition, Ohio: Thompson South-Western. 
IJBE: Integrated Journal of Business and Economics e-ISSN: 2549-3280

Mello, J. A. (2002). Strategic Human Resource Management, Cincinati: South Western.

McMillan, J. H. \& Schumacher, S. (2001). Research in Education: A Conceptual Introduction. New York: Addison Wesley Longman Inc.

Palan, R. (2008). Competency Management. Jakarta: Penerbit PPM

Ramly, A. T. (2016). Disertasi: Evaluasi Program Pelatihan Pengembangan Sumberdaya Manusia berbasis Pumping HR Model. Jakarta: Pascasarjana UNJ.

Sampurno. (2011). Manajemen Strategik: Menciptakan Keunggulan Bersaing yang Berkelanjutan. Yogyakarta: Gajah Mada University Press.

Senge, P. M. (1996). Disiplin kelima. Jakarta: Binarupa Aksara.

Sugiyono. (2005). Memahami Penelitian Kualitatif. Bandung: ALFABETA.

Ruhenda, dkk. (2013). Pedoman Akademik Universitas Ibn Khaldun Bogor. Bogor: UIKA.

Tafoya, D.W. (2010). The Effective Organization. New York: Routledge.

Thomson \& Strickland. (2003). Strategic Management, Concept \&Ccases. Newyork: McGraw Hill Higher Education.

Umar, H. (2005). Riset Sumberdaya Manusia. Jakarta: Gramedia Pustaka Utama.

Zed, M. (2008). Metode Penelitian Kepustakaan. Jakarta: Yayasan Obor Indonesia. 